\title{
PERAN PANITIA PENGAWAS PEMILU (PANWASLU) DALAM MENEKAN POTENSI POLITIK UANG PADA WILAYAH YANG DIKUASAI LOCAL STRONGMEN : STUDI PADA PEMILIHAN KEPALA DAERAH KOTA CIMAHI TAHUN 2017
}

\author{
Arlan Siddha \\ Program Studi Imu Pemerintahan, Universitas Jenderal Achmad Yani \\ E-mail :arlansidda@gmail.com \\ Witjaksono \\ Program Studi Ilmu Pemerintahan, Universitas Jenderal Achmad Yani \\ E-mail:witjaksono@gmail.com
}

\begin{tabular}{l|l|l} 
Diterima :23 April 2018 & Direvisi : 30 Mei 2018 & Diterbitkan : 30 Juni 2018
\end{tabular}

\begin{abstract}
The direct election of regional heads in a democratic system, in fact, becomes a challenge for a region to provide intelligent political education for its people. Unfortunately, however, the challenge must be tested by a group of strong people (local strongmen) an area that has its own characteristics in preserving its power for many years. Therefore, in this article, will be studied how the role of Election Supervisory Committee (Panwaslu) Cimahi City in dealing with money politics and local strongmen hegemony. This research uses descriptive qualitative method with structured interview. The results of this study show that Panwaslu Kota Cimahi runs two roles, namely the role in the preparation stage and the role at the implementation stage. Where the results of both new formal actions and has not entered into the realm of substantial
\end{abstract}

Keywords: Democracy, Pilkada, local strongmen

\section{Abstrak}

Direstuinya pemilihan umum kepala daerah secara langsung dalam sistem demokrasi, sejatinya menjadi tantangan tersendiri bagi suatu daerah untuk memberikan pendidikan politik yang cerdas bagi masyarakatnya. Namun sayangnya, tantangan tersebut harus diuji oleh sekelompok orang kuat (local strongmen) suatu wilayah yang memiliki karakteristik tersendiri dalam melestarikan kekuasaannya hingga bertahun-tahun. Maka dari itu dalam artikel ini, hendak dikaji bagaimana peran dari Panitia Pengawas Pemilu (Panwaslu) Kota Cimahi dalam menyikapi politik uang serta hegemoni local strongmen. Penelitian ini menggunakan metode kualitatif deskriptif dengan wawancara terstruktur. Hasil dari penelitian ini memperlihatkan bahwa Panwaslu Kota Cimahi menjalankan dua peran, yakni peran pada tahap persiapan dan peran pada tahap pelaksanaan. Dimana hasil dari keduanya baru tindakan-tindakan formal dan belum masuk ke ranah substansial

Kata Kunci: Demokrasi, Pilkada, local strongmen

\section{Latar Belakang}

Demokrasi dewasa ini dinilai telah menjadi konsep yang paling ideal dalam tatanan sosio-politik global. Demokrasi mulai berkembang secara pesat pasca berakhirnya perang dunia II, dimana hal tersebut diiringi dengan kemenangan demokrasi liberal sebagai kekuatan baru dunia yang dinilai solutif. Demokratisasi mulai menyebar ke seluruh penjuru dunia secara pesat. Hal ini disebabkan masih mahalnya kebebasan dalam berserikat, berkumpul serta menyatakan pendapat dalam kehidupan bernegara. Secara teoritis, demokrasi tercermin dari makna umum 
demokrasi itu sendiri, diantaranya ialah (1) adanya perlindungan hak asasi manusia, (2) menjunjung tinggi hukum, (3) tunduk terhadap kemauan rakyat, (4) adanya perlindungan terhadap kelompok-kelompok minoritas, dan (5) supremasi sipil atas militer. (Budiyanto, 2005: 53).

Di Indonesia, perkembangan demokrasi telah mengalami dinamika pasang surut yang sangat luar biasa. Selama 73 tahun berdirinya Republik Indonesia, kita banyak dihadapkan terhadap permasalahan yang berkaitan dengan bagaimana mempertinggi tingkat kehidupan ekonomi di samping membina kehidupan sosial dan politik yang demokratis, terlebih dalam masyarakat yang beraneka ragam pola budayanya. Perkembangan demokrasi seutuhnya di Indonesia diawali sejak runtuhnya pemerintahan orde baru dengan demokrasi pancasila nya. Selama 32 tahun orde baru berkuasa, rezim menghadirkan karakteristik politik utama, yaitu: (1) Lembaga kepresidenan yang terlampau dominan; (2) Rendahnya kesetaraan di antara lembaga tinggi Negara; (3) Rekruitmen politik yang tertutup; (4) Birokrasi sebagai instrument kekuasaan; (5) Kebijakan publik yang tidak transparan; (6) Sentralisasi; (7) Implementasi HAM yang masih rendah; (7) Sistem peradilan yang tidak independen. (Gaffar, 2002: 149)

Karakteristik tersebut pada akhirnya menjadi sebuah titik tolak untuk melakukan perubahan dalam konteks ketatanegaraan yang dikenal dengan istilah reformasi. Konsekuensi dari reformasi itu sendiri salah satunya ialah tuntutan penyaluran aspirasi langsung masyarakat, terlebih lagi dalam penentuan kepala pemerintahan yang secara periodik terus berproses dari pemilihan legislatif langsung, hingga kepala pemerintahan pusat maupun daerah.

Arus baru demokratisasi pada prosesnya kemudian semakin menonjol setelah diadakannya pemilu pada tahun 1999 sebagai titik tolak derasnya arus demokratisasi Indonesia. Dan kemudian pada pemilu berikutnya, yakni 2004, presiden telah dipilih secara langsung oleh rakyat. Lahirnya kemudian UU Pemerintah Daerah Nomor 32 tahun 2004 semakin menegaskan tentang pemilihan kepala daerah secara regulatif di Indonesia. Berdasarkan UU Nomor 23 tahun 2014 menyatakan bahwa: "Komisi Pemilihan Umum Daerah yang selanjutnya disebut KPU Provinsi, Kabupaten/kota sebagaimana dimaksud dalam Undang-undang Nomor 22 tahun 2003 diberi wewenang khusus oleh undang-undang ini untuk menyelenggarakan pilkada dan wakil kepala daerah di setiap provinsi dana tau kabupaten/kota"

Hal tersebut pun pada hakikatnya merupakan kepanjangan tangan dari amanat pilkada yang tercantum dalam pasal $22 \mathrm{E}$ ayat (5) UUD 1945 yang menentukan bahwa "Pemilihan umum diselenggarakan oleh suatu Komisi Pemilihan Umum yang bersifat nasional. Tetap, dan mandiri'. Dari pernyataan tersebut, jelas bahwa kemudian aturan yang berlaku secara menyeluruh bahkan ke aras daerah, menegaskan bahwa penyelenggaraan pilkada juga memerlukan KPU (dan KPUD di daerah) sebagai penyelenggara utama pemilihan kepala pemerintahan.

Berdasarkan pernyataan Syamsul Wahidin, dipilihnya KPUD sebagai penyelenggara secara mandiri dimaksudkan bukan hanya untuk efisiensi dan profesionalisme semata. Akan tetapi yang paling mendasar adalah dalam rangka menciptakan independensi. Dan dari pelaksanaan yang efisien berdasarkan asas pemilu, pada prosesnya kemudian akan berimplikasi pada pemilihan yang demokratis (Wahidin: 2008: 41). Dan dalam pengawasannya, KPUD diawasi oleh Badan Pengawas Pemilu (Bawaslu) di tingkat Provinsi, 
dan Panitia Pengawas Pemilu (Panwaslu) di tingkat Kabupaten/Kota.

Selama berlangsung sejak tahun 1955, pemilihan umum langsung tidak mungkin tidak melahirkan pelanggaran baik itu tercatat maupun tidak tercatat. Sejatinya hal-hal tersebut menjadi dinamika yang mengikuti keberlangsungan pemilihan umum langsung. Pelanggaran bahkan semakin menguat pasca pemilihan kepala daerah dilakukan secara langsung. Hal ini sejalan dengan kemunculan fenomena roving bandits pasca runtuhnya rezim Orde Baru. Menurut Agustino (2014), ketika otonomi dilaksanakan, ternyata perilaku pimpinan di daerah tidak jauh berbeda degan perbuatan elit-elit di Jakarta semasa Orde Baru berkuasa. Mereka memanfaatkan kekayaan daerah tanpa berupaya membangun daerah yang telah dieksplorasi dan dieksploitasinya. Beberapa wilayah bahkan melahirkan tokohtokoh lokal atau biasa disebut sebagai local strongmen yang pada prosesnya kemudian terjadi penguasaan daerah oleh etnik tertentu dan menihilkan etnik lainnya. (Agustino, 2014: 113115) dan pada akhirnya, elit lokal yang pada masa Orde Baru dijadikan tangan-tangan 'Jakarta' untuk merampas kekayaan daerah, kini 'orang-orang kuat daerah' sendirilah yang menyantap kekayaan daerahnya. Sayangnya, fenomena tersebut bahkan menjalar hingga detik ini.

Efek domino dari fenomena Local Strongmen itu sendiri pada akhirnya ialah lahirnya politik dinasti yang mencengkeram di daerah. Salah satu daerah yang juga diduduki oleh politik dinasti ialah Kota Cimahi. Kota Cimahi sendiri sebelum melangsungkan Pilkada, dipimpin oleh Atty Suharti, istri dari mantan Walikota dua periode Kota Cimahi, Itoc Tochija. Artinya, selama kurang lebih 15 tahun, kedua pasangan tersebut memimpin Kota Cimahi dan keduanya muncul sebagai kekuatan tunggal yang memimpin Kota Cimahi. Sayang kemudian, menjelang pilkada langsung Kota Cimahi, Itoc dan Atty ditangkap KPK. Atty terjaring operasi tangkap tangan menerima uang 500 juta rupiah yang ditransfer ke rekening Itoc Tochija dari yang dijanjikan Rp. 6 milyar terkait dengan izin Pembangunan Pasar Atas Baru senilai Rp. 57 milyar.

15 tahun berkuasa lantas tak membuat Itoc dan Atty sama sekali tidak memiliki kekuatan di daerahnya. Jaringan relasi dan bisnis jelas terbangun akibat adanya kekuatan tunggal pada suatu daerah. Asumsi penulis, jaringan relasi tersebut juga berpotensi melahirkan suap dan politik uang yang berkaitan dengan pencalonan ulang dinasti pada pilkada Cimahi terbaru. Maka dari itu, menarik kemudian bagi peneliti untuk menggali seberapa besar peran Panitia Pengawas Pemilu (Panwaslu) Kota Cimahi dalam meminimalisir kecurangan serta desakan kekuatan penguasa daerah yang terlibat langsung dalam pencalonan pemilihan kepala daerah di Kota Cimahi. Untuk mengetahui fenomena tersebut, peneliti menuangkan kedalam proposal penelitian

\section{Hasil dan Pembahasan}

Panwaslu dalam Lingkaran Dinamika Pilkada Langsung

Pasca diberlakukannya Undang-undang Nomor 32 tahun 2004 tentang Pemerintahan Daerah, pemilihan kepala daerah tidak lagi dilakukan oleh DPRD, namun telah digantikan perannya oleh rakyat secara daulat penuh. Hal ini ditegaskan pada pasal 24 ayat 5 yang menyatakan bahwa "Kepala Daerah dan Wakil Kepala Daerah sebagaimana dimaksud dalam ayat (2) dan ayat (3) dipilih dalam satu pasangan secara langsung oleh rakyat di daerah yang bersangkutan". Keberlangsungan Pilkada langsung kemudian semakin diteguhkan oleh Undang-undang Nomor 12 tahun 2008 serta undang-undang lainnya yang hingga detik ini melegalkan pemilihan kepala daerah langsung. 
Pilkada langsung pada hakikatnya merupakan alternatif untuk menjawab segala konflik dan buruknya pelaksanaan hasil pilkada tidak langsung yang dilakukan oleh DPRD dengan landasan hukum Undang undang nomor 22 tahun 1999. Pilkada langsung kemudian menjadi simbol kedaulatan rakyat dan menjadi indikator baru ciri pembangunan demokrasi yang baik serta melahirkan iklim good governance yang merata. Menurut M. Ma'ruf, ada beberapa pertimbangan penting penyelenggaraan pemilukada secara langsung bagi perkembangan demokrasi di Indonesia. Di antaranya ialah sebagai berikut: (a). Pemilukada langsung merupakan jawaban atas tuntutan aspirasi rakyat karena Presiden dan Wakil Presiden, DPR, DPD, bahkan Kepala Desa selama ini telah dilakukan pemilihan secara langsung; (b). Pemilukada secara langsung merupakan perwujudan konstitusi dan Undang-Undang dasar 1945, khususnya pada pasal 18 ayat 4; (c). Pemilukada secara langsung dipandang sebagai sarana pembelajaran demokrasi (politik) bagi rakyat (civil education); (d). Pemilukada secara langsung merupakan sebagai sarana untuk memperkuat otonomi daerah; (e). Pemilukada secara langsung merupakan sarana penting bagi proses kaderisasi kepemimpinan nasional.

Seiring dengan masuknya pemilukada dalam rezim pemilu, penyelenggaraanya pun diserahkan kepada KPU yang dalam hal ini adalah KPUD Provinsi untuk pemilu gubernur dan wakil gubernur dan KPUD Kabupaten/Kota untuk pelaksanaan Pemilu bupati/wakil bupati atau walikota/wakil walikota. Dalam hubungan ini, KPUD direpresentasikan sebagai instansi yang tugasnya menyelenggarakan pemilu yang bebas, mandiri, demokratis, dan transparan dengan asas langsung, umum, bebas, rahasia, jujur, dan adil di daerah.

Menurut Abdullah (2005: 57) Untuk melaksanakan pemilihan umum, yang tentu saja juga termasuk pemilukada maka KPU juga KPUD mempunyai tugas dan kewenangan sebagai berikut : (1). Merencanakan penyelenggaraan Kepala Daerah dan wakil Kepala Daerah; (2) Menetapkan tata cara pelaksanaan pilkada dan wakil Kepala Daerah sesuai dengan tahapan yang diatur dalam peraturan perundang-undangan;

Mengoordinasikan, menyelenggarakan dan mengendalikan semua tahapan pelaksanaan pilkada dan wakil Kepala Daerah; (4) Menetapkan tanggal dan tata cara pelaksanaan kampanye, serta pemungutan suara pilkada dan wakil Kepala Daerah; (5) Meneliti persyaratan partai politik atau gabungan partai politik yang mengusulkan calon; (6) Meneliti persyaratan calon Kepala Daerah dan wakil Kepala Daerah; (7) Menetapkan pasangan calon yang telah memenuhi persyaratan; (8) Menerima pendaftaran dan mengumunkan tim kampanye; (9) Mengumumkan sumbangan dana kampanye; (10) Menetapkan hasil rekapitulasi perhitungan suara dan mengumumkan hasil pilkada dan wakil Kepala Daerah; (11) Melakukan evaluasi dan pelaporan pelaksanaan pilkada dan wakil Kepala Daerah; (12) Melaksanakan tugas dan wewenang lain yang diatur oleh peraturan perundang-undangan; (13) Menetapkan kantor akuntan publik untuk mengaudit dana kampanye dan mengumumkan hasil audit.

Disamping itu tugas dan wewenang tersebut diatas, KPUD juga mempunyai kewajiban sebagai berikut (a). Memperlakukan pasangan calon secara adil dan setara; (b). Menetapkan standardisasi serta kebutuhan barang dan jasa yang berkaitan dengan penyelenggaraan pilkada dan wakil Kepala Daerah berdasarkan peraturan perundangundangan; (c). Menyampaikan laporan ke DPRD untuk setiap tahapan pelaksanaan pemilihan dan menyampaikan informasi kepada masyarakat; (d). Memelihara arsip dan dokumen pemilihan, serta mengelola barang 
inventaris milik KPUD berdasarkan peraturan perundang-undangan;

Mempertanggungjawabkan penggunaan anggaran kepada DPRD; (f). Melaksanakan semua tahapan pilkada dan wakil Kepala Daerah

$$
\text { Dipilihnya KPUD sebagai }
$$
penyelenggara secara mandiri dimaksudkan bukan hanya untuk efisiensi dan profesionalisme semata. Akan tetapi yang paling mendasar adalah di dalam kerangka menciptakan independensi. Penyelenggaraan dari pelaksanaan yang efisien merujuk pada upaya menyelenggarakan pemilihan dan perhitungan suara secara tepat waktu berdasarkan asas pemilu berimplikasi pada pemilihan yang demokratis.Selain itu, dengan logistik yang cukup serta biaya yang sesuai dengan kondisi setempat yang tentunya paling mengerti keadaaan dimaksud. Kondisi seperti ini menjadi sangat penting di dalam pelaksanaan pemilukada yang menjadi momentum penting bagi rakyat di daerah untuk memilih pemimpin yang diharapkan.

Selain itu, secara yuridis yang menjadi penyelenggara pemilu selain KPUD ialah Panitia Pengawas Pemilu (Panwaslu). Ketentuan yang mengatur hal tersebut ialah pasal 57 ayat (3) yang dinyatakan bahwa : "Dalam mengawasi penyelenggaraan pilkada dan wakil kepala daerah, dibentuk panitia pengawas pilkada dan wakil kepala daerah yang keanggotaannya terdiri atas unsur kepolisian, kejaksaan, perguruan tinggi, pers, dan tokoh masyarakat". bertindak sebagai pengawas terhadap KPUD yang dibentuk dan bertanggungjawab kepada DPRD.

Tugas dan wewenang panitia pengawas Pilkada meliputi : (1). Mengawasi semua tahapan penyelenggaraan pilkada dan wakil Kepala Daerah; (2). Menerima laporan pelanggaran peraturan perundang-undangan pilkada dan wakil Kepala Daerah; (3). Menyelesaikan sengketa yang timbul dalam penyelenggaraan pilkada dan wakil Kepala Daerah; (4). Meneruskan temuan dan laporan yang tidak dapat diselesaikan kepada instansi yang berwenang; (5). Mengatur hubungan koordinasi antarpanitia pengawas pada semua tingkatan.

Dengan demikian dapat disimpulkan bahwa lembaga yang bertugas dalam menyelenggarakan pilkada secara langsung ialah KPUD serta panitia pengawas. Sifat kedua lembaga ini ialah independen.Selain itu, kedua lembaga ini berperan untuk menciptakan suatu pemilihan yang demokratis sesuai peraturan perundang-undangan yang berlaku.

\section{Peran Panwaslu Kota Cimahi dalam menyikapi local strongmen di Kota Cimahi}

Berbicara tentang Local Strongmen sejatinya akan sangat sulit tanpa menyertakan terminologi lain seperti stationary bandits ataupun roving bandits. Menurut McGuire dan Olson (1996: 93) stationary bandits ialah “ $\ldots$ are rulers with long lasting base..., they also want to maximize their own incomes." Sedangkan roving bandits ialah "rationally settles down and takes his theft in the form of regular taxation and at the same time maintains a monopoly on theft in his domain, then those from whom he exact taxes will have an incentive to produce" (Olson, 1993: 568)

Secara sederhana, stationary bandits dapat digambarkan seperti bagaimana pada masa rezim diktator-represif berkuasa, seorang bandit menguasai sebuah teritori yang sangat luas dan berperan sebagai stasiun dimana banyak kelompok yang dikuasai dan dinaunginya, berkumpul dalam satu destinasi untuk mengumpulkan kekayaan dan menjaga kekuasaan pusat. Runtuhnya rezim pusat kemudian memunculkan apa yang disebut Olson sebagai roving bandits, yakni bandit-bandit kecil yang dipelihara oleh bandit besar untuk meraup keuntungan bagi stationary bandits.

Menurut Agustino (2014: 99) roving bandits adalah bandit jenis berbeda yang saat ini 
mengambil alih posisi dan peranan yang pernah dimainkan oleh bandit besar dalam level dan skala teritori yang lebih kecil. Menurut Olson dan Mcguire, Bandit jenis ini bukan hanya menjarah habis kawasan yang dikuasainya demi keuntungan mereka, tetapi juga berupaya mencari tempat atau kawasan baru untuk dijarah, tentunya dengan cara berkolaborasi dengan bandit tempatan di daerah yang akan dieksploitasinya. Dan patron klien dari stationary bandits itu sendiri lah yang kemudian bertransformasi menjadi roving bandits, yang dinamakan local strongmen. Local strongmen merupakan perubahan bentuk baru dari roving bandits yang kehilangan 'majikannya'

Dalam penelitian ini, local strongmen penulis sematkan pada rezim Itoch Tohija yang berkuasa selama kurang lebih 15 tahun dimana tongkat estafet dari kekuasaannya dilanjutkan oleh istrinya sendiri, yakni Atty Suharti. Dan Atty sendiri, mencalonkan kembali dirinya pada pemilihan kepala daerah Kota Cimahi pada tahun 2017. Melihat fenomena tersebut, jelas Panwaslu perlu bekerja ekstra keras demi menjalankan perannya sebagai lembaga yang bersih dan netral.

Untuk menggali peran dari Panwaslu Kota Cimahi, penulis membagi perannya ke dalam dua peran, yakni peran pada tahap persiapan, dan yang kedua ialah peran pada pelaksanaannya. Objek sasaran dari variabel yang penulis arahkan sendiri yakni bagaimana Panwaslu Kota Cimahi melaksanakan program pilkada yang bersih dan netral, dengan mengkaji sikap dari panwaslu Kota Cimahi terhadap Atty Suharti sebagai calon incumbent dan juga representasi dari rezim penguasa yang hegemonik.

Pada peran tahap persiapan, panwaslu Kota Cimahi melakukan beberapa penanganan preventif terkait keberlangsungan Pilkada ke depan, khususnya dalam menyikapi manuver-manuver local strongmen. Salah satu upaya yang dilakukan ialah peningkatan kualitas sumber daya manusia yang terampil dan juga netral. Sumber daya manusia tersebut diarahkan untuk menjadi anggota panitia pengawas tingkat kecamatan dan juga tenaga pengawas di TPS saat pelaksanaan yang akan dibahas pada poin berikutnya.

Rekrutmen dilakukan secara terbuka, dengan harapan upaya tersebut dapat memberikan citra bahwa panwaslu sudah bergerak secara terbuka dengan mengedepankan aksebilitas informasi ke hadapan masyarakat. Format seperti ini juga diharapkan mampu membantah argumen masyarakat bahwa panwaslu bergerak tertutup dan digerakkan oleh rezim pemerintah yang tengah berkuasa, yang kemudian akan mencalonkan diri kembali.

Selain melakukan eksternalisasi, yakni pembukaan rekruitmen untuk tenaga pengawas, panwaslu Kota Cimahi juga intens mengadakan bimbingan teknis bagi pegawai internal panwaslu Kota, juga untuk panitiapanitia pengawas tingkat kecamatan (Panwascam), hal tersebut sebagai upaya pembekalan bagi perangkat kerja panwaslu agar tim siap menghadapi berbagai keluhan dan juga paham menyikapi pelanggaran-pelanggaran yang kerap terjadi dalam proses kampanye. Internalisasi ini juga diharapkan mampu menjaga kewibawaan panwaslu karena mau bagaimanapun, panwaslu adalah pihak yang bertanggung jawab dalam hal penegakan administrasi di bidang pemilihan umum secara langsung.

Yang kedua ialah penegasan aturan yang telah ditetapkan agar peserta/calon tertib dan paham batasan dalam kampanye. Beberapa aturan yang ditetapkan dalam pilkada Kota Cimahi sejatinya masih mengacu pada aturan yang ditetapkan pusat (KPU dan Bawaslu RI). Namun yang perlu digaris bawahi ialah bagaimana panwaslu tegas dalam penerapan aturan. Panwaslu sendiri fokus pada beberapa aturan yang kerap berlaku dan relevan di 
lapangan. Berikut merupakan paparan dari Zaenal, ketua Panwaslu Kota Cimahi:

"Dalam pilkada, pasangan calon hanya boleh memfasilitasi transportasi kepada peserta kampanye, tapi bukan dalam bentuk uang. Kalaupun mau ngasih hadiah juga tidak boleh lebih dari Rp 1 juta. Jika ada salah satu pasangan calon yang kedapatan melakukan politik uang, maka pencalonannya bisa dicabut, dan yang menerimanya pun akan mendapatkan sanksi,"

\section{Ketua Panwaslu Kota Cimahi,} walaupun tidak menyiratkan secara tegas bahwa politik uang dilakukan oleh salah satu atau seluruh calon, terlebih incumbent yang memiliki jaringan luas, namun argumen tersebut setidaknya mampu menegaskan posisi panwaslu Kota Cimahi dalam rangka memerangi patologi dalam pemilu, khususnya yang dilakukan oleh calon-calon yang memiliki jaringan yang luas dan hegemonik sehingga berpotensi mempengaruhi masyarakat dengan kekuatan yang dimilikinya.

Terakhir, peran tahap persiapan dari panwaslu Kota Cimahi terkait pencegahan hegemoni local strongmen ialah, melakukan himbauan-himbauan dalam bentuk keterlibatan seluruh lapisan masyarakat untuk sama-sama mengawasi pemilihan umum kepala daerah langsung. berikut merupakan paparan dari Koordinator Divisi Pencegahan dan Hubungan Antar Lembaga Panwaslu Kota Cimahi, Yus Sutaryadi.

"Elemen pelajar dan pemuda merupakan lapisan masyarakat yang harus memiliki kontribusi besar terhadap pengawasan sehingga membantu kelancaran pilkada,"

Target sasaran dari tim panwaslu Kota Cimahi sendiri ialah generasi milenial di wilayah perkotaan, yakni pelajar dan pemuda sebagai pendatang baru dalam pesta demokrasi terakbar di wilayah Kota Cimahi. Dengan melibatkan kalangan pemuda dalam kegiatan seperti ini, pemuda akan merasa dilibatkan dan penting, sehingga, rasa berperan tersebut membangkitkan sense of belonging dalam tubuh pemuda untuk sama-sama menjaga pemilihan kepala daerah agar berjalan jujur, bebas, dan adil.

Kemudian dalam peran tahap pelaksanaan, seperti yang sudah diulas sebelumnya, panwaslu Kota Cimahi melakukan rekrutmen besar-besaran untuk tim pengawas guna ditempatkan di Tempat Pemungutan Suara (TPS) yang tersebar di seluruh Kecamatan di Kota Cimahi. Tidak tanggungtanggung, jumlah yang direkrut oleh panwaslu Kota Cimahi sebanyak 980 orang. Rekrut pun melalui sistem yang ketat, yakni melalui proses wawancara guna menghindari keberpihakan terbuka salah satu petugas terhadap salah satu calon. Terlebih lagi memang kekhawatiran tersebut cukup beralasan mengingat jaringan salah satu calon cukup menggurita.

Panwaslu Kota Cimahi kemudian terbantu oleh pengungkapan kasus korupsi yang dialami oleh Atty dan juga suaminya dalam Operasi Tangkap tangan (OT'T) yang dilakukan oleh Komisi Pemberantasan Korupsi (KPK). Sehingga kemudian, praktek-praktek yang biasa dilakukan oleh rezim terdahulu yang sudah menjadi rahasia umum, dapat berkurang dan dapat ditekan. Maka kemudian, aspek pelaksanaan hanya baru pada tahap perekrutan tenaga pengawas.

\section{Kesimpulan}

Panwaslu Kota Cimahi dalam menerapkan aturan terkait ketertiban penyelenggaraan pemilihan Kepala Daerah Langsung. sejatinya masih bergantung pada aturan-aturan pusat. Peran dan upaya yang dilakukan pun baru pada tataran perekrutan sumber daya manusia dengan fokus pada kuantitas, bukan pada kualitas. Namun upaya tersebut dirasa cukup mampu menekan asumsi mengenai keberpihakkan panwaslu terhadap salah satu calon karena rekrutmen dilakukan 
secara terbuka dan transparan. Selain itu proses internalisasi juga dilakukan yakni melalui bimbingan teknis untuk pemutakhiran pengetahuan tim panwaslu Kota Cimahi agar mampu dengan tegas menerapkan aturan demi terciptanya pemilukada yang bebas, rahasia, jujur dan adil.

Namun memang dalam perekrutan tersebut terkendala pada hal dana dan logistik. Harapan panwaslu Kota Cimahi terkait perekrutan sebanyak-banyaknya, terbentur pada fee yang disanggupi oleh mata anggaran provinsi maupun kota, sehingga banyak yang mundur dalam keterlibatannya. Panwaslu juga kurang spesifik dalam meminta golongan pemuda terlibat mengawasi pemilu. Seharusnya panwaslu juga memberikan sosialisasi terkait kondisi sosial politik kota Cimahi, ditambah sosialisasi norma-norma, khususnya terkait pelarangan money politics dan praktek kolusi lainnya yang sejatinya mampu mencederai keberlangsungan pemilu yang jujur dan adil serta netral.
Morowitz, D.L. "Demokrasi Pada Masyarakat Majemuk". Dalam Larry Diamond dan Mars F Plattner. Nasionalisme, Konflik Etnik dan Demokrasi. Bandung: ITB Press, 1998)

Rauf, M. Konsensus Politik: Sebuah Penjajagan Teoritis. (Jakarta: Direktorat Jenderal Pendidikan Tinggi Departemen Pendidikan Nasional, 2000)

Rasyid, Ryaas. Otonomi Daerah dalam Negara Kesatuan. (Yogyakarta: Pustaka Pelajar. 2002)

Riwu, Josef. Prospek Otonomi Daerah di Negara Republik Indonesia. Jakarta: Rajawali Press, 2002)

Salusu, J. Pengambilan Keputusan Stratejik untuke Organisasi Publik dan Organisasi Non-Profit. (Jakarta: Grasindo, 1998)

Weiner, M. Integrasi Politik dan Pembangunan Politik. In Y. Muhaimin, \& C. MacAndrews, Masalah-masalah Pembangunan Politik (pp. 40-49). Yogyakarta: Gadjah Mada University Press, 1977)

\section{Daftar Pustaka}

\section{Buku Teks}

Agustino, Leo, Politik Lokal dan Otonomi Daerah. (Bandung: Penerbit Alfabeta, 2013).

Feith, H.. The Decline of Constitutional Democracy in Indonesia. (Ithaca and London: Cornell University Press, 1973).

Henslin, James. M. Social Problems (2 ${ }^{\text {nd }}$ Edition). (New Jersey: Englewood Cliffs, 1990)

Labolo, Muhadam. Memahami Ilmu Pemerintahan: suatu kajian, teori, konsep, dan pengembangannya. (Jakarta: Rajawali Press, 2013)

Moleong, Lexy J. Metode Penelitian Kualitatif. (Bandung: PT Remaja Rosdakarya. 2004)

\section{Referensi Online dan Wawancara}

Febriani, Ririn Nur. "Panwaslu ajak semua pihak untuk awasi Pilkada Kota Cimahi”.http://www.pikiranrakyat.com/bandungraya/2016/11/30/panwaslu-ajak-semuapihak-awasi-pilkada-kota-cimahi-386318. Diakses pada tanggal 8 April 2018.

P, Feri, "Panwas Cimahi tambah Personel untuk Maksimalkan Pengawasan" https://jabar.antaranews.com/berita/61 364/pilkada-2017-panwas-cimahitambah-personel-untuk-maksimalkanpengawasan. diakses pada tanggal 8 April 2018.

Sutaryadi, Yus, Wawancara Pribadi, Minggu 16 Februari 2018. 
Zaenal, Wawancara Pribadi, Minggu 16 Februari 2018.

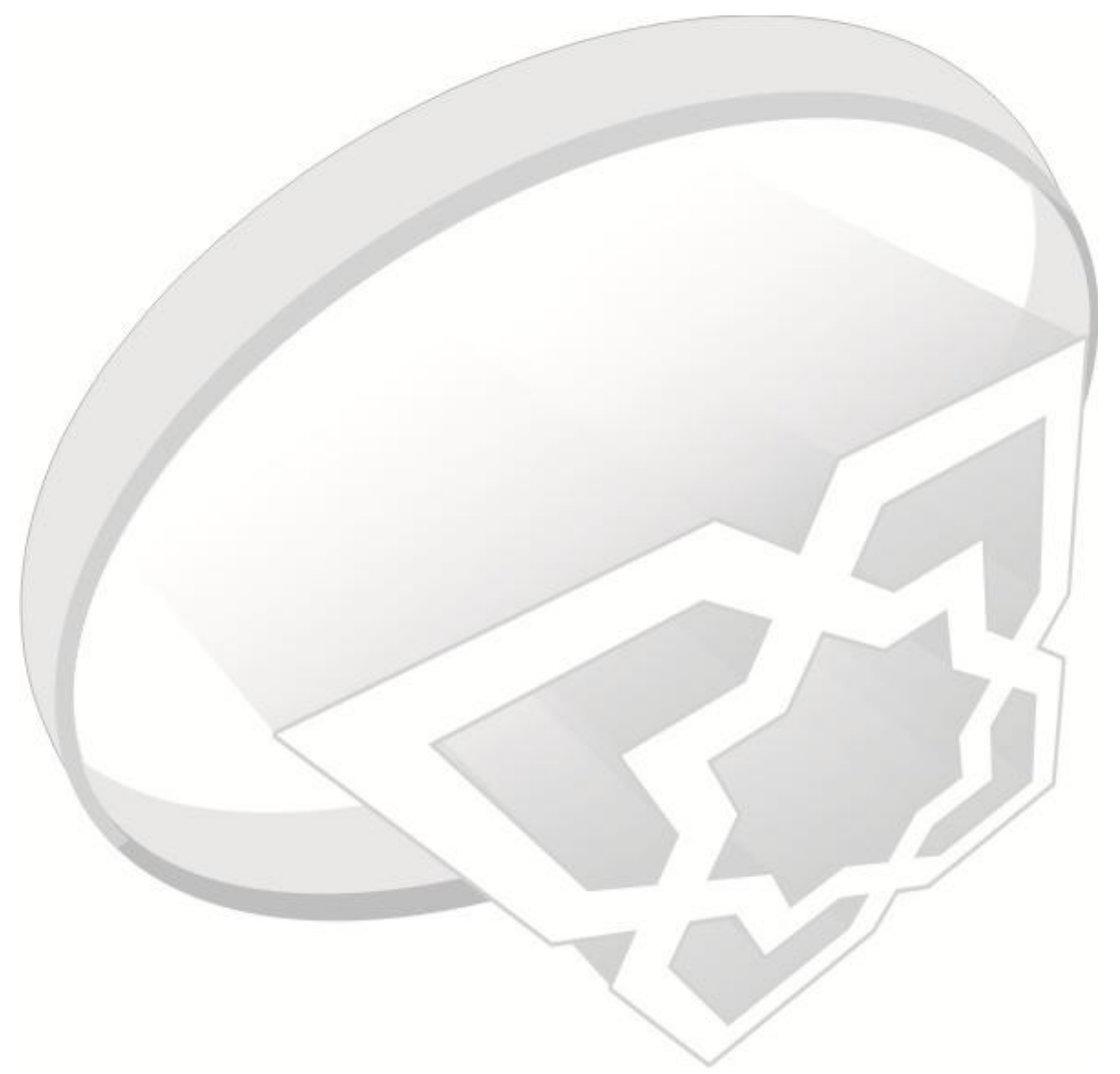

